\title{
USE OF SEISMIC REFLECTION AMPLITUDE VERSUS OFFSET (AVO) TECHNIQUES TO IMAGE DENSE NONAQUEOUS PHASE LIQUIDS (DNAPL)
}

Michael G. Waddell, Earth Sciences and Resources Institute, Univ. of South Carolina, Columbia, SC William J. Domoracki, Earth Sciences and Resources Institute, Univ. of South Carolina, Columbia, SC

Tom J. Temples, Earth Sciences and Resources Institute, Univ. of South Carolina, Columbia, SC

\begin{abstract}
Field experiments were conducted to determine the location and distribution of subsurface DNAPL contamination at two DOE sites by use of two-dimensional, high-resolution seismic reflection surveys and borehole geophysical data. These studies make use of seismic reflection amplitude versus offset (AVO) technology to directly detect the presence of subsurface free-phase DNAPL.

The research was conducted at Savannah River Site, SC and Hanford Site, WA. At each of these sites research consisted of site evaluation, seismic model studies, seismic acquisition, processing, and interpretation. The seismic model studies were undertaken prior to field acquisition to determine the likelihood of an AVO response from the DNAPL. The full Zoeppritz equations were used to create the model responses.

At M-Area, Savannah River Site the model data show that at the base of the DNAPL plume the seismic amplitude should flip polarity on the far offsets (Class 2 AVO). The 2D seismic reflection field data processed into near and far offset stacks indicate such anomalies occur at the depth where the known DNAPL occurs. At the 200 West Area, Hanford Site the DNAPL is suspected to pool at two different stratigraphic intervals. The model data show that at the upper interval, the Hanford Fine/Plio-Pleistocene boundary, amplitude should decrease along the boundary if DNAPL is present (Class 1 AVO anomaly dim-out). At the lower boundary the models show that, if DNAPL is present, the seismic amplitude should become very negative (Class 3 AVO bright spot). A series of 2D seismic lines were acquired and processed. In the areas where DNAPL was suspected to occur (high concentrations measured in wells) seismic amplitude was found to decrease dramatically along the Hanford Fine/Plio-Pleistocene contact and along the Plio-Pleistocene/caliche contact the seismic amplitudes became even more negative consistent with the model study.
\end{abstract}

\section{Introduction}

Imperative to any DNAPL remediation effort is the ability to locate high concentrations of contaminants. Traditional techniques such as borehole sampling run the risk of cross-contamination of aquifers. In addition, DNAPL can be missed because of inadequate spatial sampling. Seismic reflection profiling is a geophysical technique that can be conducted to yield horizontal measurements every foot and vertical measurements every 3-5 feet depending on the survey design. The seismic section can reveal faults, burial channels, and subsurface lows that might influence the migration of DNAPL in the subsurface.

The amplitude and arrival time of seismic waves is dependent on the elastic parameters of the subsurface including bulk modulus, shear modulus, density, and Poisson's ratio and the angle of the incidence of the impinging energy. The last two parameters can, in certain instances, be used to infer the fluid content within the pore spaces. In the Petroleum industry seismic amplitude versus offset (AVO) methods are used to directly detect hydrocarbon bearing strata. In this study we adapt some of these techniques to directly detect the 
presence of DNAPLs at the U.S. Department of Energy Savannah River Site and Hanford Site (Waddell and Domoracki, 1997; Waddell et al., 1999).

\section{Objectives and Methodology}

The primary objective of this study was to test the feasibility of using high-resolution seismic techniques and direct hydrocarbon indicator analyses to image free-phase and dissolved phase DNAPLs. Other objectives were to use the seismic data to map the subsurface geology and to determine the geologic controls on the distribution of the DNAPL at the sites investigated.

The approach taken was three fold consisting of 1) evaluation of existing geological and geophysical data concerning the amount and distribution of DNAPL, 2) seismic modeling to determine whether or not an AVO anomaly would be expected from DNAPL saturated sediments, 3) acquisition and processing of seismic data designed specially to image the DNAPL.

\section{Modeling}

The most important aspect to this study is the AVO modeling, which was used to design the field acquisition parameters for the seismic profiles. The models were generated using the full Zoeppritz equations (after Graul and Hilterman, 1994). The model for SRS is a sand wedge saturated with either water or TCE overlying either a clay layer or a water saturated sand. The model for Hanford is layer model along the two stratigraphic contacts where $\mathrm{CCl}_{4}$ is known to accumulate. For all models the pore space was assumed to be completely filled by DNAPL, air, or water depending on the scenario investigated.

\section{USDOE Savannah River Site}

The Savannah River Site (SRS) is located in South Carolina on the South Carolina-Georgia border. The M-Area seepage basin was constructed in 1958 to contain uranium wastes and residual solvents produced from reactor fuel and target degreasing operations (Fig. 1). An estimated 900K kg of residual solvents were released into the thirty million liter unlined surface impoundment over a period of nearly thirty years. In 1988 the basin was closed, backfilled, and covered with an impermeable cap. Chlorinated solvents, including free-phase constituents, have been detected in the groundwater near the seepage basin since 1981. The majority of the DNAPL found in the subsurface is composed of Trichloroethylene (TCE), Tetrachloroethylene (PCE), and Trichloroethane (TCA). Water samples taken from well MSB-3D (Fig. 1) consisted of a separate phase liquid composed of PCE with a subordinate amount of TCE (Looney, 1992).

The near-surface geology at the M-Area seepage basin consists of Eocene age Upper Coastal Plain sedimentary units (Fig. 2). The "green clay" is contained in the Warley Hill Formation and ranges in thickness from 0 to 3 meters at a depth of approximately 47.2 meters below the surface. This clay, when present, is considered the confining unit, which separates the overlying surficial aquifer from the semi- to confined aquifer below. The DNAPL in the M-Area pools on top of the "green clay".

Using the parameters in Table 1, the results of the modeling suggested that there would be an AVO effect caused by the presence of DNAPL (Fig. 3). Furthermore, these results indicated that changes in the reflection coefficient would begin to occur at approximately $30^{\circ}$ angle of incidence. Using this information the seismic lines were designed such that half the receivers would be under this incident angle and half would be over. 


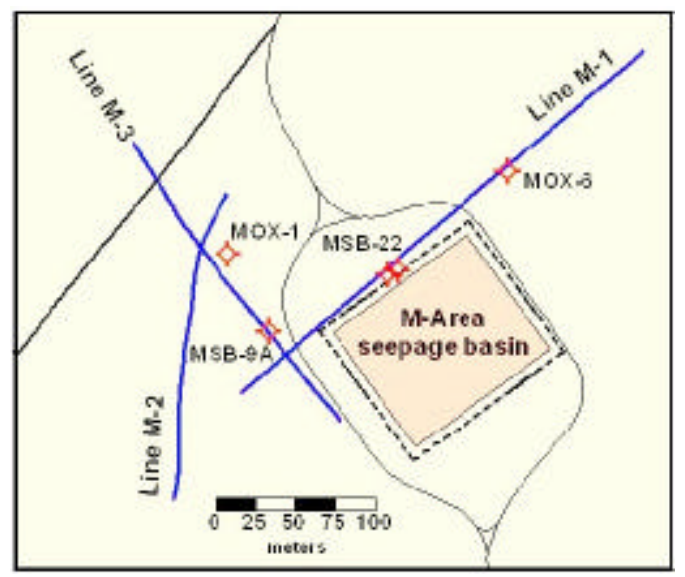

Figure 1. Location of all the 2-D seismic lines acquired for AVO analysis at M-Area seepage basin, SRS. Well MSB-3D is adjacent to MSB-22. Well MSB-3D has free-phase DNAPL at the bottom of the well.

\begin{tabular}{|c|c|c|c|c|}
\hline \multicolumn{2}{|l|}{$\begin{array}{l}\text { Period/ } \\
\text { Epoch }\end{array}$} & $\begin{array}{c}\text { North American } \\
\text { Stage }\end{array}$ & Group & Formation \\
\hline \multirow{3}{*}{ : } & \multirow{3}{*}{$\begin{array}{l}\mathscr{\Xi} \\
\text { ठ্ } \\
\text { II }\end{array}$} & Age unknown & & Upland \\
\hline & & Jacksonian & Barnwell & $\begin{array}{l}\text { Tobacco Road } \\
\text { Dry Branch }\end{array}$ \\
\hline & & Caibonmian & Orangeburg & $\begin{array}{l}\text { Santee/Tinker } \\
\text { Warley Hill } \\
\text { Congaree }\end{array}$ \\
\hline
\end{tabular}

Figure 2. Stratigraphic Column of the General Geology M-Area. The DNAPL tends to "pond" at the contact between the Santee/Tinker and the Warley Hill (green clay).

Table 1. Parameters used to generate SRS AVO models

\begin{tabular}{|l|c|c|c|}
\hline Lithology & $\mathrm{V}_{\mathrm{p}}$ & $\mathrm{V}_{\mathrm{s}}$ & Density \\
\hline & $\mathrm{m} / \mathrm{s}$ & $\mathrm{m} / \mathrm{s}$ & $\mathrm{g} / \mathrm{cc}$ \\
\hline Wedge & & & \\
\hline Water Sand & 1768 & 442 & 1.9 \\
\hline TCE Sand & 1514 & 498 & 2.07 \\
\hline Substrate & & & \\
\hline Clay & 1707 & 396 & 1.85 \\
\hline
\end{tabular}




\begin{tabular}{|l|l|l|l|}
\hline Water Sand & 1707 & 445 & 1.89 \\
\hline
\end{tabular}

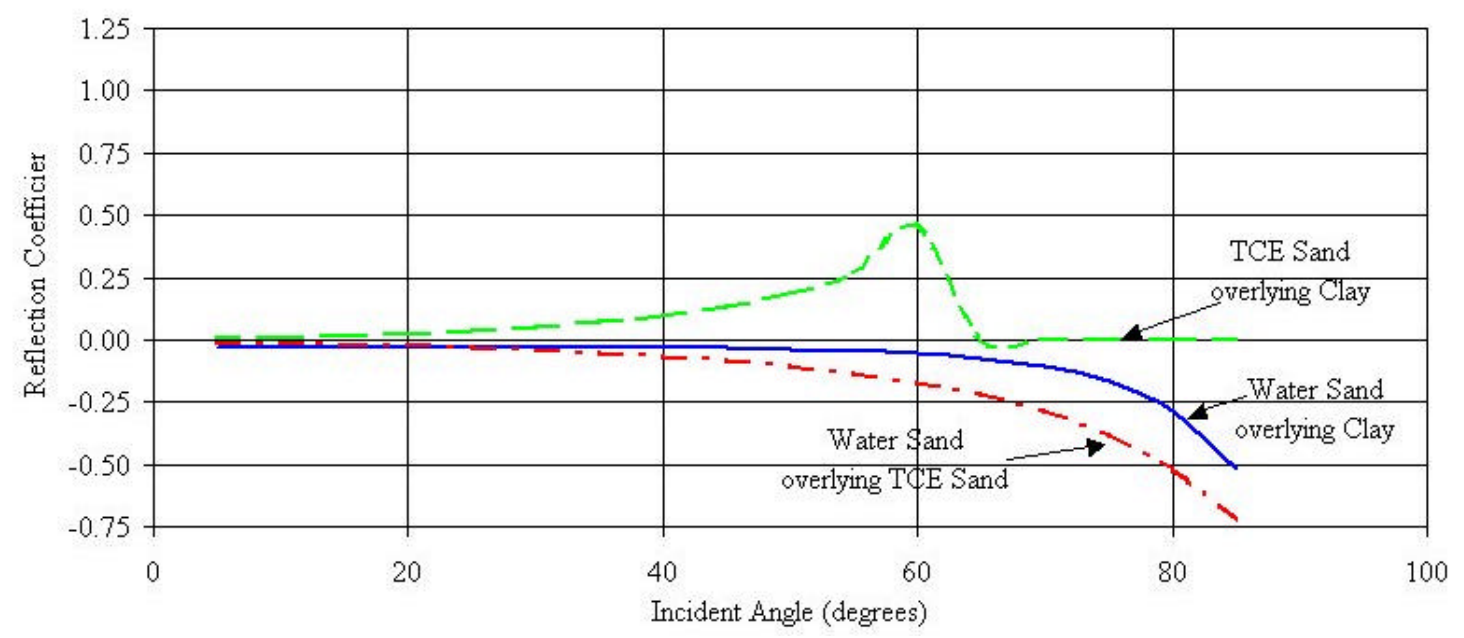

Figure 3. Graph of reflection coefficient versus angle of incidence using the Zoeppritz equations for water saturated sand overlying TCE saturated sand, middle graph is for water saturated sand overlying the "green clay." The lower graph is the reflection coefficient versus angle of incidence for water saturated overlying the sand

\section{Seismic Data Acquisition and Processing}

The original project consisted of recording one seismic profile, line M 1 , across a known DNAPL plume that has a free-phase component (well MSB-3D)(Fig. 1). After processing M-1 a preliminary AVO analysis (fluid factor stack) was preformed and an anomaly was detected at the location and depth of the known DNAPL plume. As a result, it was decided to acquire two additional lines M-2, and M-3 and a vertical seismic profile (VSP) at well MSB-9A (Fig. 1).

All of the data were collected with a 24 bit OYO DAS-1 seismograph recording either 48 channels (M-1) or 96 channels (M-2 and M-3). Several sources (mini-vibrator, downhole Seisgun ${ }^{\mathrm{tm}}$, EWG- ${ }^{\mathrm{tm}}$ weight drop source, and $3.6 \mathrm{~kg}$ sledgehammer) were tested. The sledgehammer was found to be a repeatable high frequency source that generated a relatively small surface wave.

The acquisition parameters for seismic line M-1 appear in Table 2. The parameters were based upon the modeling results. The target interval was the "green clay" aquitard at approximately 47.2 meters depth. The recording offsets were chosen in such a way as to have at least 15 to 20 geophone groups under $30^{\circ}$ angle of incidence so that the AVO analysis described above could be preformed on the seismic lines.

Table 2. Seismic Acquisition Parameters Line M-1, SRS

\begin{tabular}{|l|l|l|l|}
\hline Number of channels & 48 & Nominal CDP fold & 24 \\
\hline Group interval & $0.61 \mathrm{~m}$ & Geophone freq. & $40 \mathrm{~Hz}$ \\
\hline Shot interval & $0.61 \mathrm{~m}$ & Source & Hammer / 8 hits \\
\hline Near offset & $6.1 \mathrm{~m}$ & Sample rate & $0.25 \mathrm{~ms}$ \\
\hline
\end{tabular}




\begin{tabular}{|l|l|l|l|}
\hline Far offset & $34.75 \mathrm{~m}$ & Record length & $500 \mathrm{~ms}$ \\
\hline
\end{tabular}

The seismic data were processed with standard CDP data processing sequence (Yilmaz, 1987) that included frequency-wave number filtering (F-K or pie slice filtering) to eliminate linear noise trains, spiking deconvolution, and iterative velocity analysis and residual statics application. For display, the data were filtered to a $90-275 \mathrm{~Hz}$ passband and five point running mean was applied to enhance the lateral continuity of reflections. To analyze AVO variations, near and far offset stacks were generated as well as a Smith and Gidlow (1997) fluid factor stack.

\section{Amplitude Analysis}

In this project two methods were used to investigate any AVO effects caused by the presence of DNAPL. If the models were correct, there would not be any significant change in amplitude under $30^{\circ}$. Method one was ranged limited stacking. In this method data were gathered and stacked using subsets of the range of offsets to produce a near offset section (Fig. 4 top) and far offset section (Fig. 4 middle). AVO anomalies produced by the presence of DNAPL should show as high amplitudes present on the far offset section, but not on the near offset section.

The second AVO analysis technique used was the Smith and Gidlow "fluid factor" stack (Smith and Gidlow, 1987) (Fig. 4 bottom). The "fluid factor" stack is derived from the Aki and Richards (1980) approximation of Zoeppritz equations and the Castagna, Batzle and Eastwood (1985) "mudrock line" for $100 \%$ water saturated clastic silicate rocks. In this method a series of time and space variant weighting factors are applied to the CDP gather after NMO (normal moveout) corrections. If the model is valid, the CDP stack will be zero for $100 \%$ water saturated clastic sediments. Any residual reflections should denote sediments saturated with fluids other than water. In this project DNAPL would be the only fluid other than water to saturate or partially saturate the sediments.

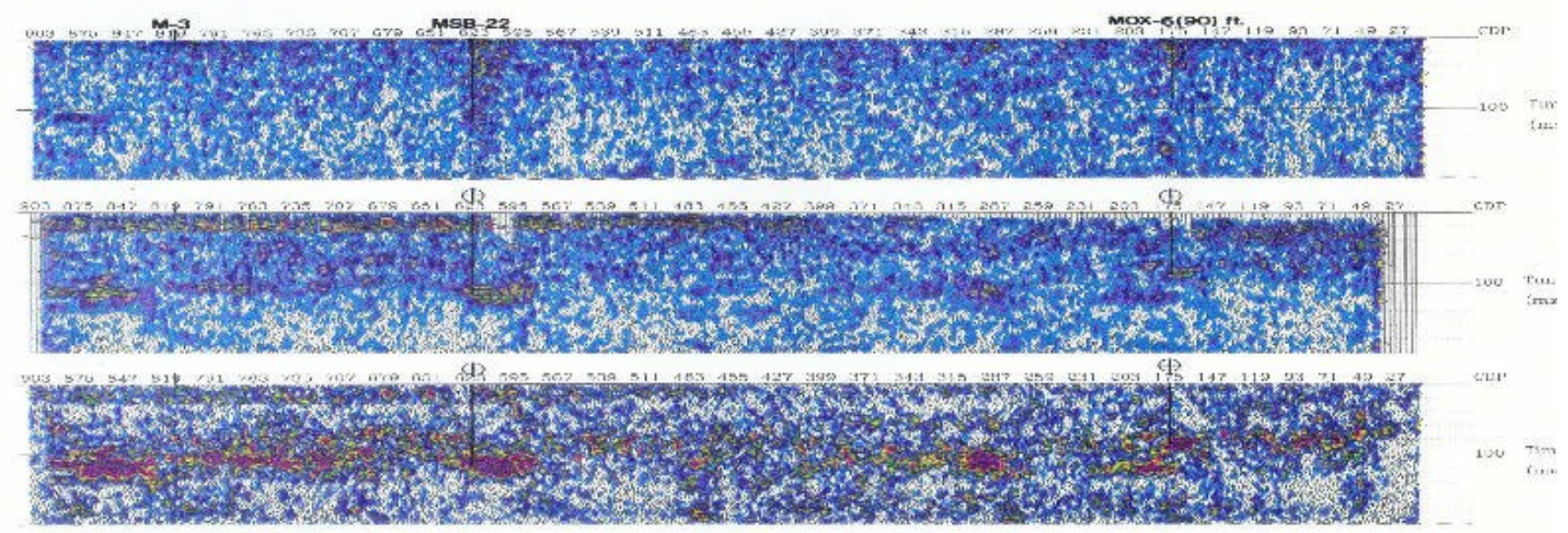

Figure 4. Offset range limited stacks and fluid factor stack for profile M-1. Near offset section (top), far offset (middle), and fluid factor (bottom). The middle section was generated by stacking offsets greater than $17.68 \mathrm{~m}$. High amplitudes that occur only at far offsets should denote presence of DNAPL. The bottom section is a fluid factor stack of M-1. Well MSB-3D is adjacent to MSB-22. The water table occurs at a depth corresponding to approximately $100 \mathrm{~ms}$ time. The amplitude envelope (magnitude of Hilbert transform) is displayed. 


\section{Profile M-1 Direct DNAPL Detection}

In Figure 4 the upper profile is a near offset stack and the middle profile is a far offset stack. If there are any AVO anomalies, they should be present on the far offset stack and absent on the near offset stack. At shot point 79 at $89 \mathrm{~ms}$ is an anomaly that was drilled (well MOX-6) and TCE was found to be present. Another anomaly at shot point 297 at 109 ms had free-phase DNAPL (MSB-3D). Another anomaly is at shot point 430 at $110 \mathrm{~ms}$ which is believed to be DNAPL, but is untested.

Figure 4 (bottom) is a fluid factor stack based upon the Smith and Gidlow (1987) weighted stack technique. The amplitude anomalies observed on the far offset stack are present. The anomaly observed on the far offset range limited stack at shot point 79 at $89 \mathrm{~ms}$ is present as are the other anomalies at shot points 297 at $109 \mathrm{~ms}$ and shot point 430 at $110 \mathrm{~ms}$.

\section{West Area USDOE Hanford Site}

The Plutonium Finishing Plant at USDOE Hanford Site utilized quantities of carbon tetrachloride $\left(\mathrm{CCl}_{4}\right)$ as a heavy liquid separator during plutonium recovery operations. Between 1955 and 1973 and estimated 360-580K liters of carbon tetrachloride were discharged into waste facilities at $200 \mathrm{~W}$ est area. The study area is adjacent to the 216-Z-9 crib, 200 W est area which was one of the disposal sites (Fig. 5). At this location there is a 10 sq. $\mathrm{km}$ subsurface plume of highly concentrated $\mathrm{CCl}_{4}$. Contamination is found throughout the $\sim 65 \mathrm{~m}$ thick unsaturated zone and in the groundwater. A pproximately 65 percent of the original estimated $\mathrm{CCl}_{4}$ volume is unaccounted for and might be held as residual concentration in the soil pore spaces of both the unsaturated and saturated zone.

At 200 W est A rea approximately $150 \mathrm{~m}$ of Tertiary and Quaternary fluvial deposits overlie M iocene age Columbia River flood basalts (Fig. 6). The fluvial deposits are differentiated into the Ringold Formation (Pliocene) $(-110 \mathrm{~m}$ thick) and the $\mathrm{H}$ anford Formation (Pleistocene) $(\sim 40 \mathrm{~m}$ thick). The $\mathrm{H}$ anford Formation consists of sand and gravel deposits that can be subdivided into an upper unit and a lower unit, the Hanford Fine. At the base of the Hanford Formation is a unit about $8 \mathrm{~m}$ thick consisting of carbonate cemented reworked silt and sand deposits designated "Plio-Pleistocene" (PP). U nderlying the PP is a caliche layer that varies in thickness and continuity. Borehole data indicates that the highest concentrations of $\mathrm{CCl}_{4}(\sim 37,000 \mathrm{ppb})$ have accumulated at the contact of the Hanford Fine with the Plio-Pleistocene (37 m depth) and at the contact of the Plio-Pleistocene with the underlying caliche zone (41 $\mathrm{m}$ depth).

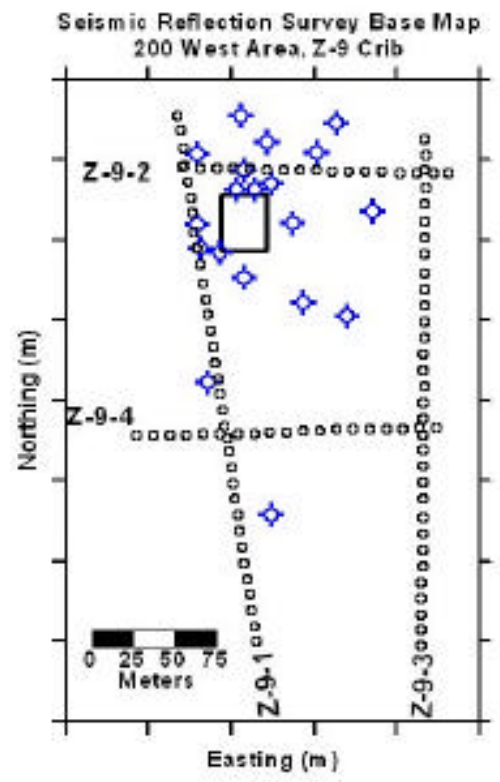


Figure 5. Location of seismic lines, wells, and 216-Z-9 crib (small rectangle) at 200 West area, Hanford Site.

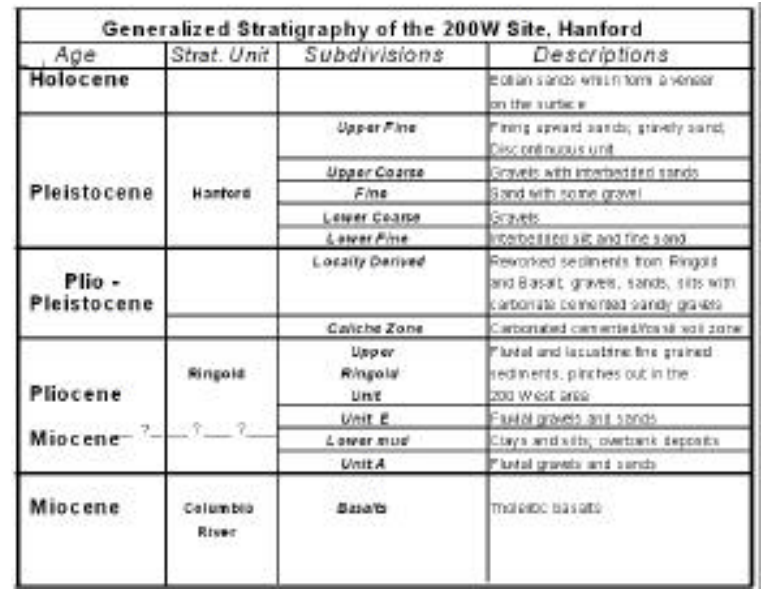

Figure 6. Generalized stratigraphic column for the 200 West Area, Hanford Site.

\section{Modeling}

Five different scenarios were modeled 1) the contact of the Hanford Fine (air) overlying the PlioPleistocene (air)(Fig. 7), 2) Hanford Fine ( $\left.\mathrm{CCl}_{4}\right)$ overlying the Plio-Pleistocene (air)(Fig. 7), 3) the contact of the Plio-Pleistocene (air) with the caliche (air)(Fig. 8), 4) the Plio-Pleistocene (water) overlying the caliche $\left(\mathrm{CCl}_{4}\right)$ (Fig. 8), and 5) the Plio-Pleistocene (air) overlying the caliche (CCh) (Fig. 8). The modeling parameters in Table 3 were based on published density measurements, vertical seismic profile velocities, and velocities theoretically determined using the Gassmann theory of fluid saturated rocks (e.g. White, 1983). Porosity is 35 percent.

At the contact of the Hanford Fine and the Plio-Pleistocene there is a positive reflection coefficient of approximately 0.7 . However, if the Hanford Fine is saturated with $\mathrm{CCh}$, the reflection coefficient drops to - 0.1 , resulting in a "dim-out." At the Plio-Pleistocene-caliche contact the reflection coefficient is approximately 0.15 . If the caliche is saturated with $\mathrm{CCl}_{4}$ the reflection coefficient at the contact increases from 0.18 to 0.38 . This is referred to as a "bright-spot." If the Plio-Pleistocene is saturated with water and the caliche is saturated with $\mathrm{CCl}_{4}$ at about $38^{\circ}$ angle of incident there is flip in the reflection coefficient going from a positive to negative that would be an AVO effect.

The results of the model study indicate that significant changes in angle dependant reflectivity should occur if the pore spaces are saturated with $\mathrm{CCl}_{4}$. These results were used to design the seismic acquisition program.

Table 3. AVO Modeling Parameters, Hanford Site

\begin{tabular}{|l|c|c|c|}
\hline \multicolumn{1}{|c|}{ Lithology } & $\mathrm{V}_{\mathrm{p}} \mathrm{m} / \mathrm{s}$ & $\mathrm{V}_{\mathrm{s}} \mathrm{m} / \mathrm{s}$ & Density $\mathrm{g} / \mathrm{cc}$ \\
\hline Hanford Fine & 620 & 394 & 1.56 \\
\hline Hanford Fine w/CCl $/ \mathrm{Cl}_{4}$ & 1287 & 336 & 2.13 \\
\hline Plio-Pleistocene & 1351 & 679 & 1.18 \\
\hline
\end{tabular}




\begin{tabular}{|l|c|c|c|}
\hline Plio-Pleistocene w/CCl & 1671 & 596 & 2.32 \\
\hline Plio-Pleistiocene w/water & 2017 & 808 & 2.14 \\
\hline Caliche & 2103 & 679 & 1.49 \\
\hline Caliche w/CCl & 1966 & 447 & 2.58 \\
\hline
\end{tabular}

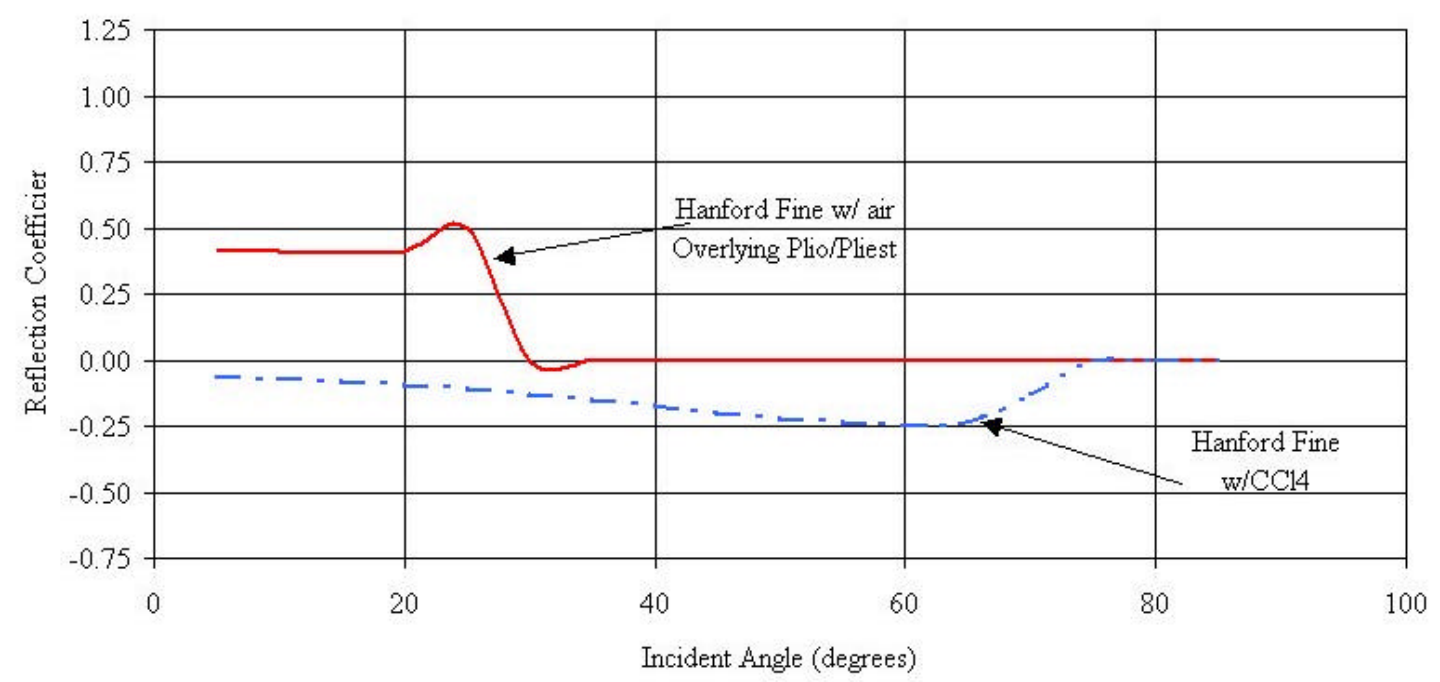

Figure 7. Graph of reflection coefficient versus angle of incidence for air saturated Hanford Fine overlying air saturated Plio-Pleistocene. Graph of reflection coefficient versus angle of incidence for $\mathrm{CCl}_{4}$ saturated Hanford Fine overlying air saturated PlioPleistocene.

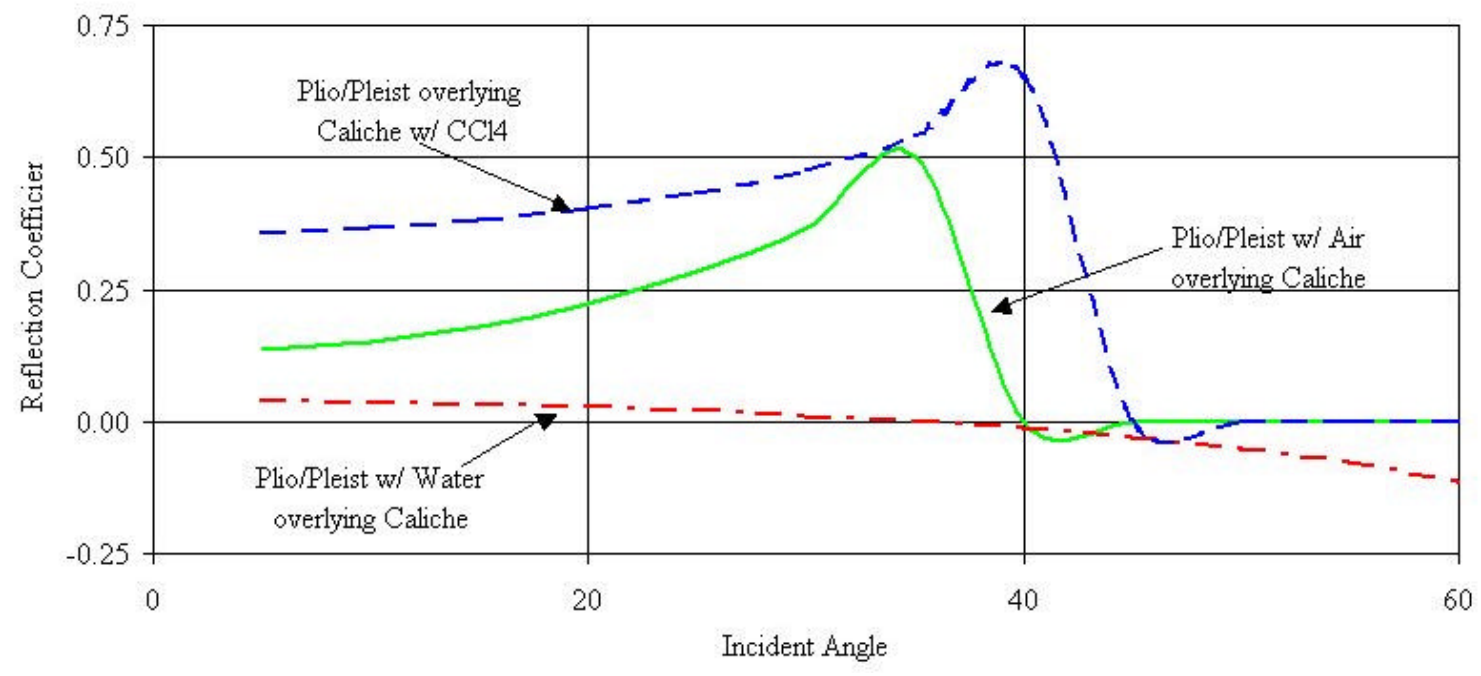

Figure 8. Graph of reflection coefficient versus angle of incidence for air saturated PlioPleistocene overlying air saturated caliche. Graph of reflection coefficient versus angle of incidence for water saturated Plio-Pleistocene overlying air saturated caliche. Graph of reflection coefficient versus angle of incidence air saturated Plio-Pleistocene overlying the $\mathrm{CCl}_{4}$ saturated caliche. 
Four seismic reflection profiles were collected to encompass the Z-9 crib (Fig. 5). These profiles are designated lines Z-9-1, Z-9-2, Z-9-3, and Z-9-4. A single vibrator source and a 120 channel Geometrics StrataView seismograph were used to record the data. Because the caliche layer is a strong acoustic boundary and is near the $\mathrm{CCl}_{4}$ contaminated layers, the seismic acquisition parameters were chosen to best image this interval. Other considerations included having adequate temporal and spatial sampling for high-resolution recording and attenuation of acoustic noise. The parameters used to record the seismic profiles are listed in Table 4.

Each seismic line was taken through a standard processing scheme to generate sections for structural interpretation. Line Z-9-1 (Fig. 9) is representative of the data quality obtained. Additional processing was undertaken to enhance amplitude variations in the stacked data for interpretation purposes. The amplitude of each sample was replaced with 10 raised to the power of the scaled and balanced sample amplitude. The result is that high amplitude values are exponentially boosted whereas low amplitude values are suppressed. This method aided interpretation of the caliche event. Interpretation of the Plio-Pleistocene event was made on the standard processed sections. No enhancement was necessary to identify the decrease in amplitude (dim-out) along this event.

Table 4. Seismic Acquisition Parameters, Hanford Site

\begin{tabular}{|l|l|l|l|}
\hline Number of Channels & 120 & Cable geometry & $(\mathrm{m}) 40.5-0.5-$ VP-0.5-78.5 \\
\hline Group Interval & $1.0 \mathrm{~m}$ & Geophone freq. & $40 \mathrm{~Hz}$ \\
\hline Shot Interval & $1.0 \mathrm{~m}$ & Sample rate & $0.5 \mathrm{~ms}$ \\
\hline Source & Vibrator $5400 \mathrm{~kg}$ pk force & Record length & $7.0 \mathrm{~s}$ \\
\hline Sweep & $30-300 \mathrm{~Hz}, 6.0 \mathrm{~s}$, linear & Nominal CDP fold & 60 \\
\hline
\end{tabular}

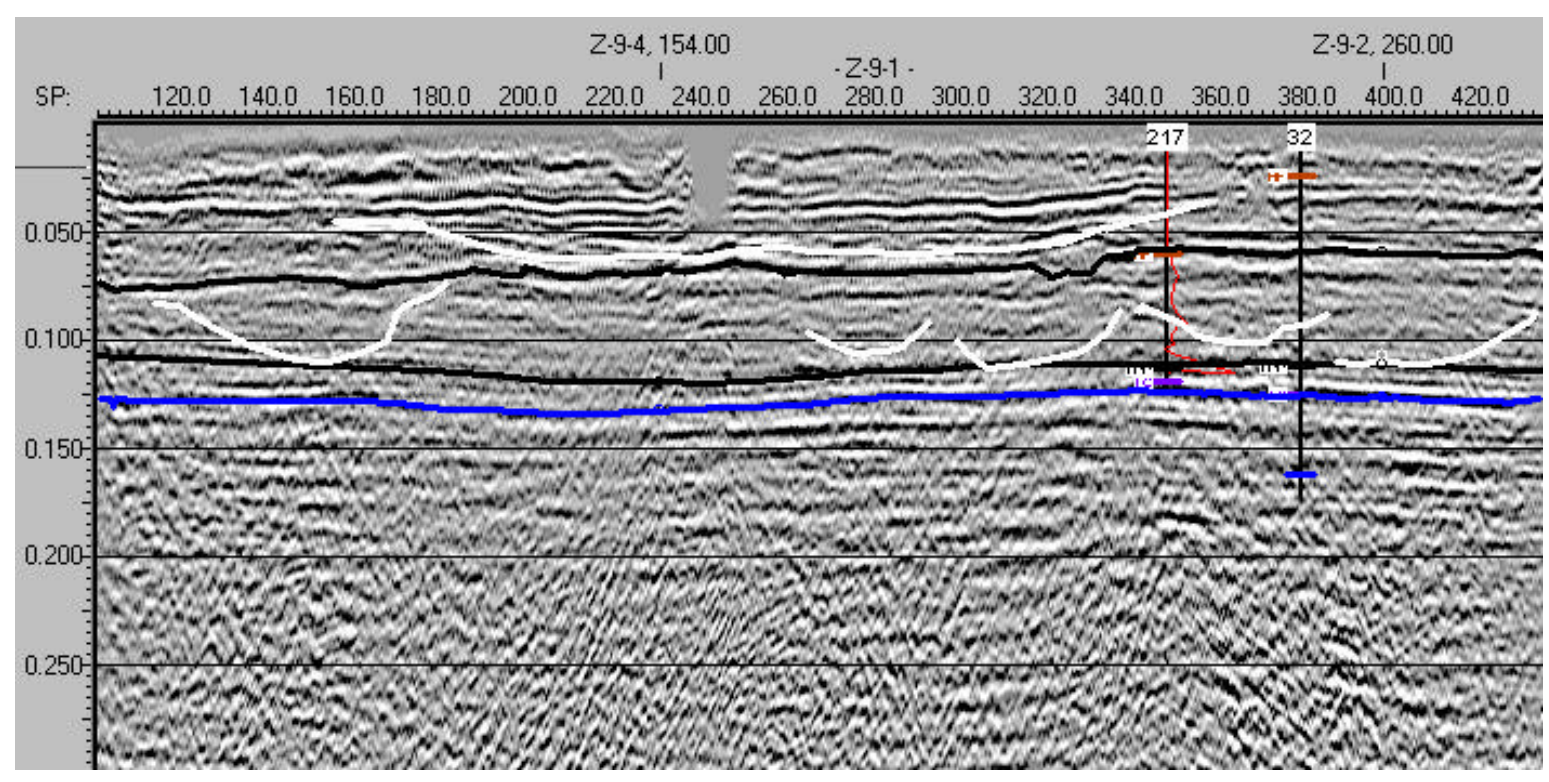

Figure 9. Seismic line Z-9-1 at 200 West Area Hanford Site. Line direction is south to north, left to right. The upper black line is the top of the Hanford Fine, the lower black line is the top of the PlioPleistocene, and the blue line is the top of the caliche layer. The concave features (white lines) are 
channels within the Hanford Formation.

\section{Interpretation of Plio-Pleistocene and Caliche}

Figure 10 is a contour map of the seismic amplitude at the top of the Plio-Pleistocene horizon. Modeling of this horizon shows that in the presence of $\mathrm{CCl}_{4}$ the amplitude along this event should be reduced, i.e. a dim-out. In general, these areas are located under the crib, to the east of the crib, and west of the crib. These reduced amplitude zones are located in structural lows along the surface of the Plio-Pleistocene. According to Rohay and others (1994) well 299-W15-217 had the highest $\mathrm{CCl}_{4}$ concentrations measured (37, $817 \mathrm{ppb}$ ) in the study area at a depth of $34.7 \mathrm{~m}$ (Plio-Pleistocene).

Figure 11 is the amplitude map on the top of the caliche reflector. Based on the model study, a high amplitude event at the top of the caliche is associated with the presence of $\mathrm{CCl}_{4}$. Amplitude values on the caliche surface are highest along seismic line Z9-2 and are projected to run to the north. A large area encompassing contour values greater than 1.4 also displays an increase in amplitude over background. Under the assumption that an increase in amplitude indicates carbon tetrachloride, free-phase $\mathrm{CCl}_{4}$ has collected along the top of caliche in this area. The mapped amplitude values suggest that little or no $\mathrm{CCl}_{4}$ is present south and east of the crib (contour values less than 1.0).

Figure 12 is a contour map of the average concentration of $\mathrm{CCl}_{4}$ in the Plio-Pleistocene/caliche interval in the crib area. Information from five wells were collected and averaged over the interval represented by the Plio-Pleistocene and gridded. The northwest area of the map shows the highest concentration values.

The carbon tetrachloride concentration map agrees well with the amplitude anomaly maps of the top of Plio-Pleistocene (Fig. 10) and the top of caliche (Fig. 11). The area directly under well 299-W15-218 is an overlay on all maps. The seismic data showing the position of free-phase in the subsurface agrees well with the known concentrations based on the well data.

Based on the close agreement between the seismic and the well data, a prediction of the location of free-phase $\mathrm{CCl}_{4}$ can be made. The seismic event, when enhanced, yields a distinctive anomaly that can be mapped with high confidence.

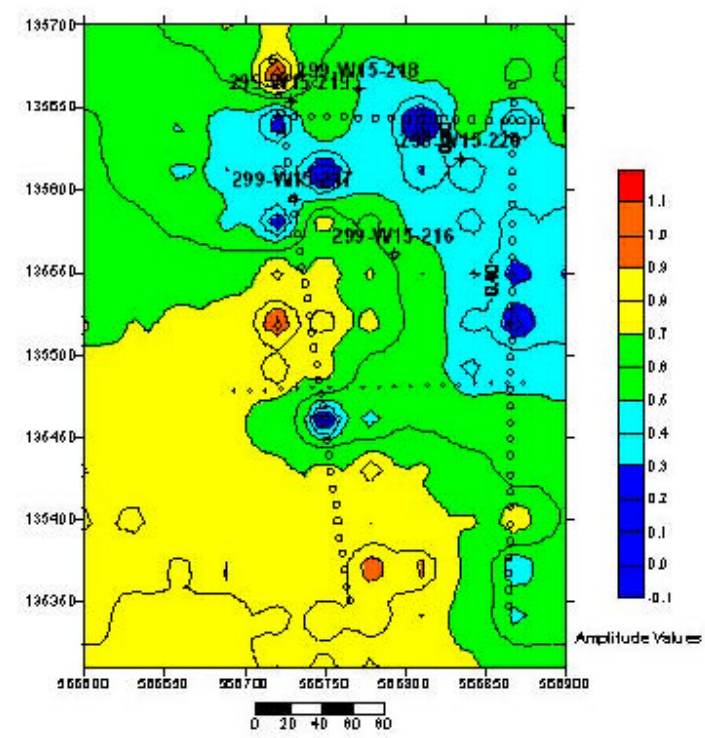

Figure 10. Contour map of amplitude values PlioPleistocene. Amplitude values are arbitrary.

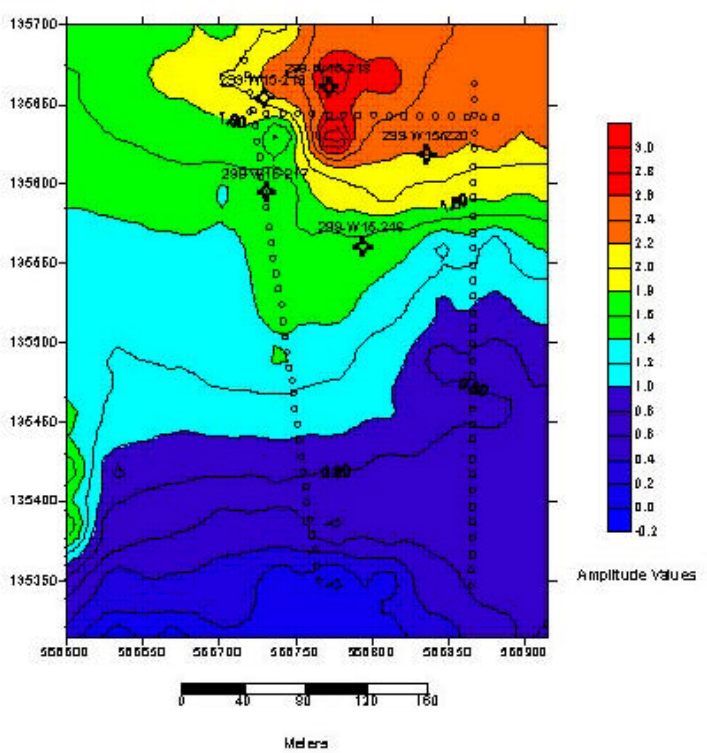

Figure 11. Contour map of amplitude values top of caliche. Amplitude values are arbitrary. 


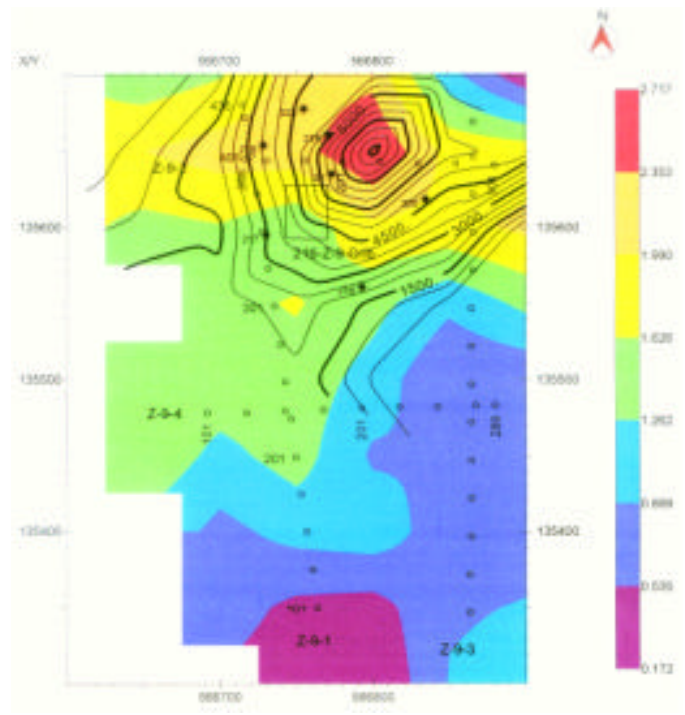

Figure 12. Carbon tetrachloride isoconcentration map at top of caliche. Contour interval in ppmv. Shaded contours are amplitude at top of caliche (arbitrary values).

\section{Conclusions}

At the M-Area seepage basin, Savannah River Site it appears that DNAPLs can be imaged in the subsurface using high-resolution seismic data. Two wells were drilled on anomalies recognized by the seismic data and DNAPLs were found at the predicted depth in parts per million (head space data).

The seismic amplitude anomalies detected at 216-Z-9 crib, 200 West, USDOE Handford Site agree well with model predictions of AVO and stack response for carbon tetrachloride saturated and unsaturated units. It appears that the seismic amplitudes are responding to the presence of high concentration of carbon tetrachloride. At the contact between the Hanford Fine and the Plio-Pleistocene seismic models predict that an amplitude decrease, a dim-out, should occur where there is high concentration $\mathrm{CCl}_{4}$. This is clearly evident on the contour map of the top of Plio-Pleistocene reflection amplitudes. The seismic models generated for the PlioPleistocene/caliche contact with the Plio-Pleistocene saturated with $\mathrm{CCl}_{4}$ show that an increase in amplitude should occur due to $\mathrm{CCl}_{4}$. The amplitude map for the top of caliche shows high amplitudes where there is high concentration of $\mathrm{CCl}_{4}$ on top of the caliche.

Caution must be exercised in applying this technique to other areas. Before any seismic data are acquired some basic modeling has to be done. The modeling will determine what is the minimum amount of DNAPL that can be imaged given the geologic conditions for a particular site and provide the necessary data for designing seismic acquisition parameters.

\section{Acknowledgments}


Funding for this project was provided by the U.S. Department of Energy. We would also like to thank Mike Graul at Texseis, Inc. of providing the initial modeling data. We also thank Hampson-Russel Software Services Ltd. for donating their AVO software and Seismic Micro Technology for donating their KINGDOM software. The University of South Carolina-ESRI acknowledges support of this project by Landmark Graphics Corporation via the Landmark University Grant Program.

\section{References}

1. A ki, K. and P.G. Richards (1980), Quantitative Seismology, W.H. Freeman and Co., San F rancisco, 932 p.

2. Castagna, J.P., M.L. Batzle, and R.L. Eastwood, R.L. (1985), "Relationships between compressionalwave and shear-wave velocities in clastic silicate rocks", Geophysics, v. 50, pp. 571-581.

3. Graul, M . and F. Hilterman (1994), AVO-Seismic Lithology, SE G Continuing Education course notes, Society of Exploration Geophysicists, Tulsa, OK.

4. Looney, B.B. (1992), Assessing DNAPL Contamination in A/M Area, SRS: Phase 1, W SR C report W SR CRP-92_1302, Prepared for U.S. Department of Energy under Contract No. DE-A C09-89SR 18035, W estinghouse Savannah River Company, Aiken, SC, 85 p.

5. $\quad$ Rohay, V.J., K.J. Swett, and G.V. Last (1994), Conceptual Model of the Carbon Tetrachloride Contamination in the 200 West Area at the Hanford Site, WHC report WHC-SD-EN-TI-248, Westinghouse Hanford Company, Richland, WA.

6. Smith, G.C. and P.M. Gidlow (1987), "Weighted stacking for rock property estimation and detection of gas", Geophysical Prospecting, v. 35, pp. 993-1014.

7. Waddell, M.G. and W.J. Domoracki (1997), Delineating DNAPLS Using 2-D Shallow High Resolution Reflective Seismic at the Savannah River Site, South Carolina, ESRI technical report ESRI-97-F121-1, Earth Sciences and Resources Institute, University of South Carolina, Columbia, $\mathrm{SC}, 46 \mathrm{p}$.

8. Waddell, M.G., W.J. Domoracki, T.J. Temples, and J. Eyer (1999), Non-Invasive Determination of the Location and Distribution of Free-Phase Dense Nonaqueous Phase Liquids (DNAPL) by Seismic Reflection Methods, Interim Report for Tasks 1, 2, and 3, Prepared for U.S. Department of Energy under Award No. DE-AR26-98FT40369, Earth Sciences and Resources Institute, University of South Carolina, Columbia, SC, 88 p.

9. White, J.E. (1983), Underground Sound-Application of Seismic Waves, Elsevier, New York, 253 p.

10. Yilmaz, O. (1987), Seismic Data Processing, SEG Investigations in Geophysics No. 2, Society of Exploration Geophysicists, Tulsa, OK, 526 p. 